\title{
Performance of dairy cows fed diet containing concentrate with fermented Durio zibethinus peel
}

\author{
Endang Sulistyowati ${ }^{1 *}$, Irma Badarina ${ }^{1)}$, Sigit Mujiharjo ${ }^{2)}$, Sistanto ${ }^{1)}$, Icuk Rahma Dhani ${ }^{1)}$, \\ Ririn Putri ${ }^{1)}$, Enita Terimasari ${ }^{1)}$, Aji Proyogi ${ }^{1)}$, Bogi Al Iman ${ }^{1)}$, and Sawaluddin \\ Fanhar ${ }^{1)}$ \\ ${ }^{1)}$ Department of Animal Science, Faculty of Agriculture, University of Bengkulu, \\ Bengkulu 38371, Indonesia \\ 2) Department of Agricultural Technology, Faculty of Agriculture, University of Bengkulu, \\ Bengkulu 38371, Indonesia
}

Submitted: 23 May 2019, Accepted: 06 January 2020

\begin{abstract}
ABTRACT: The effects of inclusion of Durio zibethinus peel meal fermented with Pleurotus ostreatus in concentrate of diet have been evaluated in dairy cows in 4 x 4 Latin Square. Diets containing $11.35 \%$ in dry matter basis of four ratios of fermented Durio (FD) peel meal to rice bran in concentrate, there were FD0/30, FD10/20, FD20/10, and FD30/0. Experimental periods were 4- 2 week periods, with 2 weeks preliminary, daily milk recordings, and 4 days feces collection per periods. Fermentation for 2 weeks of Durio peel meal increased moisture, ash, ether extract, and doubled in crude protein; and decreased dry and organic matters and two third in crude fiber. Nutrient contents of concentrate containing fermented Durio peel meal were enhanced in moisture; decreased in dry and organic matters, ether extract, $\mathrm{N}$ - free extract, and gross energy; and stable in crude protein and crude fiber. The FD20/10 was lower in crude fiber fraction and fatty acid profile, optimal in in vitro characteristics and milk fatty acid profile, highest in milk production, milk fat weight, and milk protein weight, highest in crude protein and crude fiber digestibility. In general, diet containing concentrate with $20 \%$ fermented Durio peel meal and $10 \%$ rice bran is considered optimal for improving milk quality and digestibility in dairy cow.
\end{abstract}

Key words: durio peel meal; p. ostreatus; milk quality; digestibility

*Corresponding Author: esulistyowati@unib.ac.id 


\section{INTRODUCTION}

Durio zibethinus Murr is a fruit harvested in a year around in Indonesia and some other Asean countries as well. Its production is abundant and its by-products (seed and spiky outer peel with thick inner skin) can be utilized as feed ingredient after some treatments applied on it. Fermentation of inner peel part with Pleurotus ostreatus has been reported to enhance crude protein and lowered ether extract (Sucianti, Sulistyowati and Fenita, 2015) and improved crude fiber fractions (Sulistyowati et al., 2016). This feed ingredient could be included into concentrate in diet of ruminants, including lactating dairy cows in an expectation to improve milk production and milk quality.

Milk fatty acid in milk is most considered for healthy life. It could be modified in diet provided for dairy cow. Fatty acids sources in this present diets were roasted ground corn and palm oil. These ingredients together with yeast and Curcuma xanthorrhiza Roxb were reported by Sulistyowati, Badarina and Santoso (2010), as optimal in producing PUFA and n6/n3 designated for dairy cows. Palmitic acid supplementation in short term did not increase milk yield, fat, and protein levels, yet, did improve C-16 fatty acid in milk, C16 fatty acid apparent digestibility, and total fatty acid in milk as reported by Rico, Ying and Haryatine (2014).

Yeast supplementation data were compiled that there have increased dry matter intake, milk production, milk fat, organic matter digestibility, and total VFA (Desnoyers et al., 2009); had no effect on dry matter intake and milk fat (Bagheri et al., 2009); increased n-3 in dairy cow milk (Yalçın et al., 2011); and produced stable quantity of milk yield in pre, during, and post treatment of dairy goat (Sulistyowati et al., 2014 ${ }^{\mathrm{a}}$ ). Supplementation of both $0.5 \%$ yeast and a medicinal herb, 2\% Curcuma xanthorrhiza Roxb, containing curcuminoids and tannins bioactives, was reported as an optimal combination to maintain milk production with fatty acid quality in milk of dairy goat (Sulistyowati et al., 2013); in vitro characteristics were optimal (Sulistyowati et al., 2014 ${ }^{\mathrm{b}}$ ); and the quality of nutrients of this concentrate after 6 weeks of storage remained stable (Sulistyowati et al., 2015).

The objective of the present experiment was to elaborate the effects of Durio peel meal fermented with Pleurotus ostreatus inclusion in concentrate of diet. Parameters observed were nutrients, in vitro, in vivo, milk production and milk quality. The nutrient variables were nutrient content and fatty acid composition. The in vitro characteristics were $\mathrm{pH}$, dry matter and organic matter digestibility, total volatile fatty acid (VFA), and NitrogenAmmonia (N-NH3). The in vivo included nutrient intakes and digestibility, milk yield and milk quality in dairy cow.

\section{MATERIALS AND METHODS}

\section{Time and place of the experiment}

This research consisted of several steps with its duration of time. Preparation of fermented $D$. zibethinus peel meal starting from collecting Durio peel up to readily to be formulated in concentrate took 10 weeks. Application of this concentrate was conducted for four- 2 week periods and 2 weeks of preliminary study at Dairy farm in Kepahiang, Bengkulu. Laboratory analyses took 6 weeks, while data analyses was 6 weeks. All together, this research finished in 32 weeks or 8 months.

\section{Preparation of fermented $D$. zibethinus peel meal and concentrates}

It was started with collecting the Durio peel, cleaning, then cutting the spikes of the peel, slicing the white part of the inside peel (about $1 \mathrm{~mm}$ thick), drying under the sun for 3 days, then grinding them as meal. This Durio peel meal was then fermented with Pleurotus ostreatus. Procedure of the fermentation was conducted as reported separately by Sulistyowati, Badarina and Mujiharjo (2018). After two weeks of fermentation, 
this Durio peel meal was ready to be formulated in concentrate. The concentrates were determined by different levels of fermented Durio peel meal in substitution with rice bran.

There were formulas of concentrates with four ratios of fermented Durio (FD) to rice bran, FD0/30, FD10/20, FD20/10, and FD30/0. Other ingredients were $30 \%$ ground corn, $32 \%$ soybean meal, $3.5 \%$ palm oil, $0.5 \%$ mineral mix, $1.5 \%$ Curcuma xanthorrhiza Roxb powder, $1 \%$ yeast, $0.5 \%$ $\mathrm{NaCl}, 0.5 \% \mathrm{CaCO} 3$, and $0.5 \%$ TSP as reported previously by Sulistyowati, Badarina and Mujiharjo (2018). Yeast and Curcuma xanthorrhiza Roxb powder were prepared according to (Sulistyowati et al., 2013).

\section{Chemical analyses}

The four fermented Durio peel meals and concentrates were analyzed in PAU IPB Laboratory, for proximate analyses (DM- dry matter, OM- organic matter, CPcrude protein, EE- ether extract, $\mathrm{CF}$-crude fiber contents) according to AOAC (2005) and gross energy. A calculation of $100 \%$ $(\%$ ash $+\% \mathrm{CP}+\% \mathrm{CF}+\% \mathrm{EE})$ is identified as $\mathrm{N}$ - free extract (NFE). Fractions of crude fiber were analyzed according to (Goering and Van Soest, 1970) in Nutrition and Feed Technology Laboratory at IPB. Minerals of $\mathrm{Ca}$ and $\mathrm{P}$ were assayed using Atomic Absorbance Spectrophotometer, AA 7000 Shimadzu Co AAS and In vitro analysis was conducted to evaluate $\mathrm{DM}, \mathrm{OM}$ in vitro digestibility, $\mathrm{N}$ $\mathrm{NH} 3$ and total VFA of the four concentrates according the procedure of (Tilley and Terry, 1963) in Dairy Nutrition Laboratory at IPB.

Milk fatty acids identified as fatty acid methyl ester (FAME) were analyzed after extraction of milk fat samples, according to (Golay and Dong, 2015). Using GC- FID, 2010 Plus, Shimadzu, Japan, separation and quantification of the FAME were conducted in Integrated Basic Science Laboratory at IPB. Fatty acids were classified as follows: $\mathrm{C}<16$ consisting of short chain fatty acid $(C<10)$, medium chain fatty acid (C12- C16), and long chain fatty acid $(\mathrm{C}>\mathrm{C} 16)$, polyunsaturated fatty acid (PUFA), ratio of n6/n3: (linoleic acid + arachidonic acid)/linolenic acid (Schmidely, Morand- Fehr and Sauvant, 2005).

\section{Experimental design and data collection}

Diet ingredients and compositions with concentrate containing Durio zibethinus peel meal fermented with $P$. ostreatus were provided for dairy cow, as much as $2 \mathrm{~kg}$ /day (11.35\%); forages $(65.43 \%)$ and commercial concentrate $(24.12 \%)$ of diet dry matter, were provided daily as reported previously by (Sulistyowati, Badarina and Mujiharjo, 2018). Diets were allocated in Latin Square 4 x 4 for four lactating Fries Holland cows (in the range of $425-460 \mathrm{~kg}$ ), four formulas, and four-2 week periods, with 2 weeks of preliminary study. Data were tabulated and analyzed for variance, further analysis to detect any significant differences will be conducted using Duncan Multiple Range Test (DMRT) if any significant differences were found (Lentner and Bishop, 1986).

Daily milk production was recorded in the mornings and afternoon milkings. Forages, corn stover, King grass (Pennisetum purpureum), and rice straw as well as concentrates were provided in mornings and afternoons. Any orts were weighed in the mornings. Water was provided ad lib., recorded in the mornings. Milk samples were collected in the last afternoon and the last morning of each period, then were composited for milk fat, protein, lactose, and somatic cell count (SCC) analyses.

Feces collections were conducted in the last four days of each period; taken as much as 10\%, air dried, grounded for proximate analyses and energy content. Apparent digestibility (\%) was calculated as intakes of nutrient subtracted by nutrients in feces, divided by intakes of nutrient. Application of the diets were conducted at dairy farm in upland $(900 \mathrm{~m}$ asl) of Kabawetan, Kepahiang, Bengkulu 
with average daily temperature of $21.68^{\circ} \mathrm{C}$ and moisture of $92.68 \%$ (Sulistyowati et al., 2018).

\section{RESULTS AND DISCUSSION Nutrient Contents of concentrate with fermented Durio- peel meal}

Nutrients offermented Durio peel meal were improved compared to nonfermented one as presented on Table 1. Moisture content of fermented Durio peel meal increased, the material was much more moist when it was harvested after 2 weeks of fermentation. Therefore, its dry matter, organic matter, and $\mathrm{CF}$ were decreasing; while ash, EE, CP were improved, especially $\mathrm{CP}$ was than doubled compared to nonfermented Durio peel meal.

Fermented Durio peel meal in substitution with rice bran in different ratios decreased in DM, OM, EE, NFE, and GE; however, crude protein and crude Fiber relatively remained stable with FD 20/10 and FD 30/0 in concentrate. Ether extracts dropped markedly in FD 20/10 and FD 30/0. This suggested that the EE content in fermented Durio peel meal was low, the higher the level of fermented Durio peel meal in the concentrate, the lower EE in the concentrate of FD 20/10 and FD 30/0.

Table 1. Nutrient contents of Durio zibethinus peel meal after 2 weeks of fermentation with

\begin{tabular}{lcc} 
P. ostreatus & & \\
\hline Nutrients (\% DM) & Non fermented (\%) & Fermented (\%) \\
\hline Moisture & 5.11 & 14.92 \\
Dry matter (DM) & 94.88 & 83.68 \\
Organic matter (OM) & 95.44 & 93.33 \\
Ash & 4.55 & 6.66 \\
Ether extract (EE) & 1.22 & 2.09 \\
Crude protein (CP) & 7.01 & 16.49 \\
Crude fiber (CF) & 32.13 & 10.54 \\
\hline
\end{tabular}

Table 2. Nutrient contents of the ingredients in ration with concentrate containing Durio zibethinus peel meal fermented with $P$. ostreatus

\begin{tabular}{lcccccccc}
\hline \multicolumn{1}{c}{ Ingredients } & $\begin{array}{c}\text { Moist } \\
\text { ure } \\
(\%)\end{array}$ & $\begin{array}{c}\text { Dry } \\
\text { matter } \\
(\%)\end{array}$ & $\begin{array}{c}\text { Organic } \\
\text { matter } \\
(\%)\end{array}$ & $\begin{array}{c}\text { Ether } \\
\text { extract } \\
(\%)\end{array}$ & $\begin{array}{c}\text { Crude } \\
\text { protein } \\
(\%)\end{array}$ & $\begin{array}{c}\text { Crude } \\
\text { fiber } \\
(\%)\end{array}$ & $\begin{array}{c}\text { N free } \\
\text { extract } \\
(\%)\end{array}$ & $\begin{array}{c}\text { GE } \\
(\text { cal/g }\end{array}$ \\
\hline FD0/30 concentrate & 10.27 & 89.74 & 83.27 & 12.42 & 14.45 & 8.76 & 47.64 & 4455 \\
FD10/20 concentrate & 12.28 & 87.72 & 83.02 & 13.34 & 14.64 & 4.59 & 50.45 & 4605 \\
FD20/10 concentrate & 23.59 & 76.42 & 69.69 & 4.33 & 12.88 & 7.97 & 44.51 & 4022 \\
FD30/0 concentrate & 29.42 & 70.58 & 65.30 & 5.22 & 14.17 & 6.40 & 39.51 & 3676 \\
Farm concentrate & 14.12 & 85.88 & 77.28 & 1.66 & 14.22 & 10.87 & 64.66 & - \\
Corn forage & 75.23 & 24.77 & 44.62 & 1.40 & 13.46 & 28.05 & 1.72 & 2258 \\
King Grass & 87.63 & 12.37 & 66.56 & 1.20 & 3.96 & 27.22 & 34.18 & 3087 \\
Rice straw & 79.86 & 20.14 & 63.03 & 1.06 & 12.27 & 27.50 & 22.19 & 3059 \\
\hline
\end{tabular}

Fermented Durio 0/30 rice bran; Fermented Durio 10/20 rice bran; Fermented Durio 20/10 rice bran; Fermented Durio 30/0 rice bran.

On the other hand, farm concentrate and forages were higher in $\mathrm{CF}$ and lower in $\mathrm{OM}, \mathrm{EE}$, and GE (Table 2). Gross energy of fermented Durio peel meal concentrates were higher than those in other feed used in this experiment; moreover, the FD10/20 was $929 \mathrm{cal} / \mathrm{g}$ higher than that in FD 30/10.
The CP contents in fermented Durio peel meal concentrates, FD 10/20 and FD 30/0, were about in the same levels as required for small breed dairy cows with $10-20 \mathrm{~kg} / \mathrm{d}$ milk yield and $4 \%$ fat milk is $13.1-14.1 \%$ (NRC, 2001). This is due to the fact that fermentation could loosen lignin bond that 
crude fiber in Durio peel meal decreased, other nutrients would be available for the growth of $P$. ostreatus therefore crude protein increased. The length of fermentation in Durio peel meal with $P$. ostreatus for 8 weeks increased crude protein but lowered ether extract (Sucianti, Sulistyowati and Fenita, 2015).

\section{Crude fiber fractions and in vitro characteristics}

Crude fiber fraction, hemicelluloses was decreasing with increasing the level of fermented Durio peel meal of 20 and 30\% (Table 3). In fermentation of Durio peel meal for 4- 6 weeks was able to improve NDF, hemicelulose and ADF (Sulistyowati et al., 2016). However, in this current fermented Durio peel meal (FD 20/10) with 2 weeks fermentation had lower fiber fractions (NDF, ADF, cellulose, and lignin) that it was considered better in digestibility rates compared to other forages. Calcium and Phospor required in lactating dairy cow with $450 \mathrm{~kg}$ body weight were 18 and $13 \mathrm{~g}$, respectively or about 1.39 (NRC, 1989). The $\mathrm{Ca} / \mathrm{P}$ ratio in four formulas of concentrate containing fermented Durio peel meal were higher than it was required.

Table 3. Fractions of fiber and Calcium and Phosphor contents of concentrate with Durio zibethinus peel meal fermented with $P$. ostreatus

\begin{tabular}{lcccc}
\hline Item & FD0/30 & FD10/20 & FD20/10 & FD30/0 \\
\hline NDF, \% & 44.95 & 47.73 & 23.26 & 27.50 \\
Hemicelulose & 30.24 & 29.44 & 8.17 & 4.78 \\
ADF & 14.71 & 18.29 & 14.19 & 22.72 \\
Celulose & 9.74 & 13.2 & 9.21 & 14.75 \\
Lignin & 3.39 & 4.54 & 3.9 & 7.69 \\
Silica & 1.58 & 0.55 & 1.07 & 0.28 \\
$\mathrm{Ca}$ & 0.58 & 0.65 & 0.73 & 0.74 \\
$\mathrm{P}$ & 0.36 & 0.37 & 0.37 & 0.40 \\
$\mathrm{Ca} / \mathrm{P}$ & 1.61 & 1.76 & 1.97 & 1.85 \\
\hline
\end{tabular}

Fermented Durio 0/30 rice bran; Fermented Durio 10/20 rice bran; Fermented Durio 20/10 rice bran; Fermented Durio 30/0 rice bran

Table 4. Fatty acid contents of concentrate containing Durio zibehinus peel flour fermented with $P$. ostreatus

\begin{tabular}{lcccc}
\hline \multicolumn{1}{c}{ Items $(\mathrm{g} / 100 \mathrm{~g}$ fatty acid) } & FD0/30 & FD10/20 & FD20/10 & FD30/0 \\
\hline Total fatty acid & 77.86 & 82.29 & 69.14 & 72.21 \\
$\mathrm{C}<16$ & 0.23 & 0.30 & 0.31 & 0.41 \\
$\mathrm{C}>16$ & 77.63 & 82.01 & 68.79 & 71.8 \\
PUFA & 0.04 & 0.04 & 0.17 & 0.14 \\
Unsaturated & 57.95 & 59.52 & 48.22 & 48.03 \\
n6/n3 & 9.32 & 9.69 & 11.64 & 11.89 \\
\hline
\end{tabular}

Fermented Durio 0/30 rice bran; Fermented Durio 10/20 rice bran; Fermented Durio 20/10 rice bran; Fermented Durio 30/0 rice bran

Fatty acid contents of concentrates containing Durio peel meal fermented with Pleurotus ostreatus are presented in Table 4. Fatty acid contents of concentrate containing Durio peel meal in FD 20/10, in averages were lower in $\mathrm{C}>16$ and unsaturated; however it was higher in PUFA. Sulistyowati et al. (2016), reported that 8 weeks of fermentation of Durio peel meal decreased profiles of short chain fatty acids (SCFA), medium chain fatty acids (Med CFA) or $\mathrm{C}<16$, long chain fatty acids (Long CFA), mono unsaturated fatty acid (MUFA), poly unsaturated fatty acid (PUFA), unsaturated, and saturated or C $>16$. Fatty acid contents of $\mathrm{C}<16$ was 
about 16.4 and $\mathrm{C}>16$ was $77.8 \mathrm{~g} / 100 \mathrm{~g}$ of total fat in diets with $2.8 \%$ corn oil inclusion as reported by Boerman, Preseault and Lock (2014); our result was lower in $\mathrm{C}<16$ compared to this $4 \%$ inclusion of palm oil concentrate. This is suggested that the type of oil will determine the type and the quantity of fatty acids in diet. In vitro characteristics of concentrate containing Durio zibethinus peel meal fermented with $P$. ostreatus are presented in Table 5.

In averages, the lower the fermented Durio peel meal, the lower the $\mathrm{pH}$; yet, the higher the IVDMD, IVOMD, N-NH3, and VFA in FD 30/0.

Table 5. In vitro characteristics of concentrate containing Durio zibethinus peel meal fermented with $P$. ostreatus

\begin{tabular}{lrrrr}
\hline Items & FD0/30 & FD10/20 & FD20/10 & \multicolumn{1}{c}{ FD30/0 } \\
\hline $\mathrm{pH}$ & 6.85 & 6.77 & 6.76 & 6.71 \\
IVDMD (\%) & 65.43 & 69.75 & 74.90 & 78.14 \\
IVOMD (\%) & 64.89 & 69.09 & 73.90 & 77.02 \\
N-NH3 (mM) & 18.14 & 23.63 & 24.13 & 25.49 \\
VFA (mM) & 72.19 & 104.94 & 148.99 & 169.59 \\
\hline
\end{tabular}

Fermented Durio 0/30 rice bran; Fermented Durio 10/20 rice bran; Fermented Durio 20/10 rice bran; Fermented Durio 30/0 rice bran

Production of total VFA in concentrate with Durio peel meal fermented in 2 weeks in FD20/10 in this result, was about the same as compared to 8 weeks fermentation (Sulistyowati et al., 2016). However, the total VFA in FD20/10 and FD30/0 were higher than those with urea and yeast supplementation (Neal et al., 2014) and were higher compared to millet silage (Brunette, Baurhoo and Mustafa, 2014). (Hassanath et al., 2014) reported that replacing timothy silage with alfalfa silage did not affect total VFA which are around 118- 120 (mM). These in vitro characteristics will determine milk yield and milk quality produced. As milk production was found the highest in FD20/10 (Table 7), it is considered as the optimal ratio of fermented Durio peel meal and rice straw in concentrate.

\section{Nutrient intakes and digestibility}

Nutrient intakes of DM, OM, CP, CF, NFE of diets in this present study were decreasing very significantly $(\mathrm{P}<0.01)$ with increasing fermented Durio peel meal in concentrate as presented in Table 6. The average DMI with these diets (16.57- 17.67 $\mathrm{kg} / \mathrm{d}$ ) have fulfilled the required DMI for small breed dairy cow (454 kg) with 10- 20 $\mathrm{kg}$ milk production and $4 \%$ milk fat were between $12.4-16.0 \mathrm{~kg} / \mathrm{d}$ (NRC, 2001). The intakes of $\mathrm{DM}, \mathrm{OM}, \mathrm{CP}$, and fractions of $\mathrm{CF}$ in this present study were lower than those of diets with alfalfa hay, corn stover, and rice straw as reported by (Wang et al., 2014).

Crude protein $(\mathrm{P}<0.01)$ and crude fiber $(\mathrm{P}<0.05)$ digestibility were higher in FD 20/10, while NFE $(\mathrm{P}<0.01)$ was lower in this diet. In general, all nutrients digestibility in this study were higher in averages than those with the same forages and alfalfa hay as reported by (Wang et al., 2014) and those with $100 \%$ alfalfa silage inclusion Hassanath et al. (2014), as well as substitution with millet silage (Brunette, Baurhoo and Mustafa, 2014). Positive effects were reported on nutrient digestibility and rumen fermentation with yeast and or mannan oligosaccharide (Bagheri et al., 2009). These findings implied that our diets, containing fermented Durio peel meal supplemented with yeast and Curcuma had higher degradability. 
Table 6. Nutrient intakes and digestibilities of diet containing concentrate with Durio zibethinus peel meal fermented with $P$. ostreatus

\begin{tabular}{lccccc}
\hline Items & FD0/30 & FD10/20 & FD20/10 & FD30/0 & P \\
\hline Nutients intakes, kg/d & & & & & \\
$\quad$ Dry matter & $17.87^{\mathrm{a}}$ & $17.57^{\mathrm{ab}}$ & $16.90^{\mathrm{bc}}$ & $16.57^{\mathrm{c}}$ & $<0.01$ \\
Organic matter & $11.35^{\mathrm{a}}$ & $11.03^{\mathrm{b}}$ & $10.45^{\mathrm{c}}$ & $10.19^{\mathrm{c}}$ & $<0.01$ \\
Ether extract & $0.37^{\mathrm{a}}$ & $0.29^{\mathrm{c}}$ & $0.32^{\mathrm{b}}$ & $0.29^{\mathrm{c}}$ & $<0.01$ \\
Crude protein & $2.15^{\mathrm{a}}$ & $2.12^{\mathrm{ab}}$ & $2.01^{\mathrm{b}}$ & $1.99^{\mathrm{b}}$ & $<0.01$ \\
Crude fiber & $4.09^{\mathrm{a}}$ & $4.03^{\mathrm{ab}}$ & $3.74^{\mathrm{b}}$ & $3.69^{\mathrm{b}}$ & $<0.01$ \\
N-Free extract & $5.80^{\mathrm{a}}$ & $5.78^{\mathrm{a}}$ & $5.48^{\mathrm{b}}$ & $5.31^{\mathrm{b}}$ & $<0.01$ \\
Apparent digestibility, \% & & & & & \\
Dry matter & 74.70 & 73.13 & 72.59 & 71.59 & $>0.05$ \\
Organic matter & 73.76 & 70.03 & 69.22 & 69.16 & $>0.05$ \\
Ether extract & 70.59 & 50.83 & 65.66 & 41.09 & $>0.01$ \\
Crude protein & $72.45^{\mathrm{ab}}$ & $67.13^{\mathrm{c}}$ & $79.30^{\mathrm{a}}$ & $71.96^{\mathrm{bc}}$ & $<0.01$ \\
Crude fiber & $72.77^{\mathrm{ab}}$ & $69.57^{\mathrm{b}}$ & $81.95^{\mathrm{a}}$ & $67.04^{\mathrm{ab}}$ & $<0.05$ \\
N-Free extract & $78.14^{\mathrm{a}}$ & $77.46^{\mathrm{a}}$ & $63.40^{\mathrm{b}}$ & $75.71^{\mathrm{a}}$ & $<0.01$ \\
\hline
\end{tabular}

Fermented Durio 0/30 rice bran; Fermented Durio 10/20 rice bran; Fermented Durio 20/10 rice bran; Fermented Durio 30/0 rice bran

\section{Milk production and milk quality}

Milk yields and milk quality of dairy cows are listed in Table 7. Milk yields, milk fat weight, and milk protein weights were significantly affected $(\mathrm{P}<0.01)$ by diets containing concentrate Durio zibethinus peel meal fermented with $P$. ostreatus, the highest was in FD20/10. Among all ratios of fermented Durio peel meal to rice straw, the FD 20/10 showed the highest milk yield, there was $2.4 \mathrm{~kg} / \mathrm{d}$ higher compared to FD 10/20. These significant effects, milk yield and milk fat weight were reflected by highest intake and digestibility of ether extract as well as digestibility of crude fiber. While, highest milk protein was caused by highest protein digestibility.

In weight base, milk fat $(\mathrm{P}<0.05)$, milk protein $(\mathrm{P}<0.05)$, lactose and solid non fat (SNF) were found high in FD 20/10. Compared to other diets with corn stover and rice straw as well (Hristov et al., 2010); the inclusion of up to $100 \%$ alfalfa silage (Hassanath et al., (2014); and substitution with millet silage (Brunette, Baurhoo and Mustafa, 2014), our milk yield, milk protein, lactose and SCC were lower; while the milk fat was higher, especially in FD20/10. This was due to the diet composition of this present study that also included some forages of King grass or Pennisetum purpureum, corn stover, and rice straw, besides the fermented Durio peel meal that were high in crude fiber would be metabolized later as milk fat. The SCC mightbe due to the antimicrobial function of bioactive that is ethil acetate fraction (Anggraeni and Anam, 2016) found in Durio peel meal incorporated in the concentrate, such that it reduced the somatic cell count. These facts indicated that the inclusion of $20 \%$ of fermented Durio peel meal and $10 \%$ of rice bran in concentrate in diet was considered optimal.

Milk fatty acid of $\mathrm{C}<16$ was quantitatively high but low in $\mathrm{C}>16$ found in diet with FD 20/10 as presented in Table 8 . However, this result was lower compared to the $\mathrm{C}<16$ content of diet with $2.8 \%$ corn oil and antioxidant $(45.74 \mathrm{~g} / 100 \mathrm{~g}$ total fatty acid) as reported by Boerman, Preseault and Lock, (2014) and lower compared to the $\mathrm{C}<16$ content of diet with yeast supplementation (Hristov et al., 2010). This is suggested that the type of oil feed ingredients will affect the biohydrogenation process in rumen that eventually will determine the fatty acid composition in milk produced. The $n 6 / n 3$ ratios in dairy 
cow milk were relatively in the same range of 10.01 (FD10/20) and 10.65 (FD0/30). These ratios were much higher compared to those with extruded soybean (Schmidely, Morand-Fehr and Sauvant, 2005) and flaxseed (Cortes et al., 2010). Recommendation by $\mathrm{WHO}$ of $\mathrm{n} 6 / \mathrm{n} 3$ ratios were $5 / 1$ to $10 / 1$ (Bouattour et al., 2008). The $\mathrm{n} 6 / \mathrm{n} 3$ ratios in this present milk were somewhat tolerable in that upper limit.

Table 7. Milk production and milk quality of dairy cow fed diets containing concentrate Durio zibethinus peel meal fermented with P. ostreatus

\begin{tabular}{lccccc}
\hline Variables & FD0/30 & FD10/20 & FD20/10 & FD30/0 & P \\
\hline Milk production, kg/d* & $12.4^{\mathrm{a}}$ & $9.1^{\mathrm{b}}$ & $11.5^{\mathrm{ab}}$ & $10.5^{\mathrm{b}}$ & $<0.01$ \\
Milk fat, \% & 4.35 & 4.01 & 4.60 & 4.22 & $>0.05$ \\
Milk fat weight, kg/d & $0.54^{\mathrm{a}}$ & $0.35^{\mathrm{b}}$ & $0.53^{\mathrm{a}}$ & $0.44^{\mathrm{ab}}$ & $<0.05$ \\
Mil protein, \% & 3.11 & 3.02 & 3.04 & 3.13 & $>0.05$ \\
Milk protein weight, kg/d & $0.39^{\mathrm{a}}$ & $0.28^{\mathrm{b}}$ & $0.35^{\mathrm{a}}$ & $0.33^{\mathrm{a}}$ & $<0.05$ \\
Lactose, \% & 3.69 & 3.57 & 3.62 & 3.74 & $>0.05$ \\
Lactose, kg/d & 0.46 & 0.32 & 0.42 & 0.39 & $>0.05$ \\
Solid non fat (SNF), \% & 7.22 & 7.17 & 7.26 & 7.42 & $>0.05$ \\
Solid non fat (SNF), kg/d & 0.89 & 0.66 & 0.84 & 0.78 & $>0.05$ \\
SCC $\left(10^{3} / \mathrm{ml}\right)$ & 170 & 170 & 140 & 90 & $>0.05$ \\
\hline
\end{tabular}

Fermented Durio 0/30 rice bran; Fermented Durio 10/20 rice bran; Fermented Durio 20/10 rice bran; Fermented Durio 30/0 rice bran. *Sulistyowati et al. $\left(2018^{\mathrm{a}}\right)$.

Table 8. Milk Fatty acid contents of milk of dairy cows fed ration concentrate containing Durio zibehinus peel flour fermented with $P$. ostreatus

\begin{tabular}{lcccc}
\hline Items $(\%)$ & FD0/30 & FD10/20 & FD20/10 & FD30/0 \\
\hline Total fatty acid & 83.97 & 85.44 & 84.50 & 86.09 \\
C $<16$ & 10.22 & 13.59 & 14.50 & 14.20 \\
C $>16$ & 70.54 & 71.87 & 69.99 & 71.89 \\
PUFA & 0.17 & 0.17 & 0.18 & 0.18 \\
unsaturated & 29.50 & 30.02 & 29.18 & 30.58 \\
n6/n3 & 10.65 & 10.01 & 10.36 & 10.25 \\
\hline
\end{tabular}

Fermented Durio 0/30 rice bran; Fermented Durio 10/20 rice bran; Fermented Durio 20/10 rice bran; Fermented Durio 30/0 rice bran.

\section{CONCLUSION}

Durio zibethinus Murr peel meal fermented with Pleurotus ostreatus for 2 weeks decreased dry matter, organic matter and crude fiber; increased moisture, ether extract, and crude protein. Nutrient contents of concentrate containing fermented Durio peel meal were more moist; decreased in dry and organic matters, ether extract, $\mathrm{N}$ - free extract, and gross energy; and stable in crude protein and crude fiber. Concentrate with $20 \%$ fermented Durio peel meal and $10 \%$ rice bran was lower in crude fiber fraction and fatty acid profile, and optimal in in vitro characteristics and milk fatty acid profile.
Diet containing this concentrate showed highest in milk production, milk fat, milk fat weight, and milk protein weight, highest in crude protein and crude fiber digestibility. In general, diet containing concentrate with $20 \%$ fermented Durio peel meal and $10 \%$ rice bran is considered optimal for improving milk yield and milk quality in dairy cow.

\section{ACKNOWLEDGEMENT}

The authors would like to acknowledge Directorate General of Research and Technology, Ministry of Research and Technology and Higher Education of the Republic of Indonesia for 
funding this research under the scheme of Strategis Nasional (Stranas) with contract no: 052/SP2H/LT/DRPM/2018. Also, we would like to thank Mr. Joko for providing dairy cows for experiment in his farm in Kabawetan, Kepahiang, Bengkulu, Indonesia.

\section{REFERENCES}

Anggraeni, E. V., \& Anam, K. (2016). Identifikasi Kandungan kimia dan uji aktivitas antimikroba kulit durian (Durio zibethinus Murr.). Jurnal Kimia Sains Dan Aplikasi, 19(3), 8793. https://doi.org/10.14710/jksa.19.3 $.87-93$

AOAC. (2005). Official Method Of Analysis. In Association of Officiating Analytical Chemists (18th ed.). Washington DC.

Bagheri, M., Ghorbani, G. R., Rahmani, H. R., Khorvash, M \& Nili, N. (2009). Effect of Live Yeast and Mannanoligosaccharides on Performance of Early-lactation Holstein Dairy Cows. Asian-Australasian Journal of Animal Sciences, 22(6), 812-818. https:// doi.org/10.5713/ajas.2009.80561

Boerman, J. P., Preseault, C. L., \& Lock, A. L. (2014). Effect of dietary antioxidant and increasing corn oil inclusion on milk fat yield and fatty acid composition in dairy cattle. Journal of Dairy Science, 97(12), 7697-7705. https://doi.org/10.3168/jd s.2013-7701

Bouattour, M. A., Casals, R., Albanell, E., Such, X., \& Caja, G. (2008). Feeding soybean oil to dairy goats increases conjugated linoleic acid in milk. Journal of Dairy Science, 91(6), 2399-2407. https://doi.org/10.3168/jd s.2007-0753

Brunette, T., Baurhoo, B., \& Mustafa, A. F. (2014). Replacing corn silage with different forage millet silage cultivars: Effects on milk yield, nutrient digestion, and ruminal fermentation of lactating dairy cows. Journal of Dairy Science, 97(10),
6440-6449. https://doi.org/10.3168/jd s.2014-7998

Côrtes, C., da Silva-Kazama, D. C., Kazama, R., Gagnon, N., Benchaar, C., Santos, G. T. D., Petit, H. V. (2010). Milk composition, milk fatty acid profile, digestion, and ruminal fermentation in dairy cows fed whole flaxseed and calcium salts of flaxseed oil. Journal of Dairy Science, 93(7), 3146-3157. https://doi.org/10.3168/jd s.2009-2905

Desnoyers, M., Giger-Reverdin, S., Bertin, G., Duvaux-Ponter, C., \& Sauvant, D. (2009). Meta-analysis of the influence of Saccharomyces cerevisiae supplementation on ruminal parameters and milk production of ruminants. Journal of Dairy Science, 92(4), 1620-1632. https://doi.org/10.3168/jds.2008-1414

Goering, H. K., \& Van Soest, P. J. (1970). Forage fiber analysis. In Agricultural Handbook (pp. 1-9). Washington DC: Agricultural Research Service.

Golay, P.-A., \& Dong, Y. (2015). Determination of labeled fatty acids content in milk products, infant formula, and adult/pediatric nutritional formula by capillary gas chromatography: Single-Laboratory Validation, First Action 2012.13. Journal of AOAC International, 98(6), 1679-1696. https://doi.org/10. 5740/jaoacint.15-113

Hassanat, F., Gervais, R., Massé, D. I., Petit, H. V., \& Benchaar, C. (2014). Methane production, nutrient digestion, ruminal fermentation, $\mathrm{N}$ balance, and milk production of cows fed timothy silage- or alfalfa silagebased diets. Journal of Dairy Science, 97(10), 6463-6474. https://doi.org/10 .3168/jds.2014-8069

Hristov, A. N., Varga, G., Cassidy, T., Long, M., Heyler, K., Karnati, S. K. R., Yoon, I. (2010). Effect of saccharomyces cerevisiae fermentation product on ruminal fermentation and nutrient utilization 
in dairy cows. Journal of Dairy Science, 93(2), 682-692. https://doi. org/10.3168/jds.2009-2379

Lentner, M., \& Bishop, T. (1986). Experimental Design and Analysis. Valley Book Co. VA.

National Research Council. (1989). Nutrient Requirements of Dairy Cattle (6th ed.). Washington, D.C: National Academy Press.

National Research Council. (2001). Nutrient Requirements of Dairy Cattle (7th ed.). Washington, D.C: National Academy Press.

Neal, K., Eun, J.-S., Young, A. J., Mjoun, K., \& Hall, J. O. (2014). Feeding protein supplements in alfalfa haybased lactation diets improves nutrient utilization, lactational performance, and feed efficiency of dairy cows. Journal of Dairy Science, 97(12), 7716-7728. https://doi.org/10 .3168/jds.2014-8033

Rico, D. E., Ying, Y., \& Harvatine, K. J. (2014). Effect of a high-palmitic acid fat supplement on milk production and apparent total-tract digestibility in high- and low-milk yield dairy cows. Journal of Dairy Science, 97(6), 3739-3751. https://doi.org/10. 3168/jds.2013-7341

Schmidely, P., Morand-Fehr, P., \& Sauvant, D. (2005). Influence of extruded soybeans with or without bicarbonate on milk performance and fatty acid composition of goat milk. Journal of Dairy Science, 88(2), 757765. https://doi.org/10.3168/jds.S002 2-0302(05)72739-9

Suciyanti, H., Sulistyowati, E., \& Fenita, Y. (2016). Evaluasi nutrisi limbah kulit durian (Durio zibethinus) yang difermentasi jamur tiram putih (Pleurotus ostreatus) pada masa inkubasi yang berbeda. Jurnal Sain Peternakan Indonesia, 10(2), 77-86. https: //doi.org/10.31186/jspi.id.10.2.77-86

Sulistyowati, E., Badarina, I., \& Mujiharjo, S. (2018). Milk Production and Feed Efficiency of Dairy Cow Fed
Concentrate Containing Durio zibethinus Peel Flour Fermented with Pleurotus ostreatus. In Proceeding ISAI 4th IICC (pp. 86-90). Bogor.

Sulistyowati, E., Badarina, I., Sucianti, H., Hartono, R., \& Mujiharjo, S. (2016). Improved nutrient contents of durio zibethinus murr peel fermented with pleurotus ostreatus and its addition in PUFA- concentrate. Jurnal Sain Peternakan Indonesia, 11(1), 9-16. https://doi.org/10.31186/jspi.id.11.1.9-16

Sulistyowati, E., Santoso, U., \& Badarina, I. (2010). Milk production and modification of milk fatty acid of dairy cows fed PUFA-concentrate. Journal of the Indonesian Tropical Animal Agriculture, 35(4), 262-267. https://doi.org/10.14710/jitaa.35.4.26 2-267

Sulistyowati, E., Soetrisno, E., Mujiharjo, S., Lorence, D., Gustia, E., \& Meisella, S. (2018). Milk Production and Quality of Dairy Cow Fed Ration Containing Concentrate with Durio zibethinus Murr Seed Meal. In Presented in SAFE 6th Conference. Manila.

Sulistyowati, E., Sudarman, A., Wiryawan, K., \& Toharmat, T. (2014a). Milk Production of Late Lactation Dairy Goat Fed PUFA-Diet Supplemented with Yeast and C. xanthorrhiza Roxb. In Proc. Asian-Australasian Dairy Goat Conference 2nd. IICC (pp. 223226). Bogor.

Sulistyowati, E., Sudarman, A., Wiryawan, K. G., \& Toharmat, T. (2013). Quality of milk fatty acid during late lactation in dairy goat fed on PUFAdiet supplemented with yeast and. Journal of the Indonesian Tropical Animal Agriculture, 38(4), 247-256. https://doi.org/10.14710/jitaa.38.4.24 7-256

Sulistyowati, E., Sudarman, A., Wiryawan, K. G., \& Toharmat, T. (2014b). In vitro goat fermentation of pufa-diet supplemented with yeast and curcuma xanthorrhiza roxb. Media 
Peternakan, 37(3), 175-181. https://doi .org/10.5398/medpet.2014.37.3.175

Sulistyowati, E., Sudarman, A., Wiryawan, K. G., \& Toharmat, T. (2015). The nutritive values of pufa-concentrate supplemented with yeast and Curcuma xanthorrhiza Roxb stored in several weeks. Journal of the Indonesian Tropical Animal Agriculture, 40(1), 11-24. https://doi. org/10.14710/jitaa.40.1.11-22

Tilley, J. M. A., \& Terry, R. A. (1963). A two-stage technique for the in vitro digestion of forage crops. Grass and Forage Science, 18(2), 104-111. https: //doi.org/10.1111/j.1365-2494.1963.t b00335.x
Wang, B., Mao, S. Y., Yang, H. J., Wu, Y. M., Wang, J. K., Li, S. L., Liu, J. X. (2014). Effects of alfalfa and cereal straw as a forage source on nutrient digestibility and lactation performance in lactating dairy cows. Journal of Dairy Science, 97(12), 7706-7715. https://doi.org/10.3168/jd s.2014-7961

Yalçın, S., Yalçın, S., Can, P., Gürdal, A. O., Bağc1, C., \& Eltan, Ö. (2011). The nutritive value of live yeast culture (Saccharomyces cerevisiae) and its effect on milk yield, milk composition and some blood parameters of dairy cows. AsianAustralasian Journal of Animal Sciences, 24(10), 1377-1385. https:/ /doi.org/10.5713/ajas.2011.11060 